\title{
Researching the Optimal Irrigation Regime in China's Zhuozhang River Basin
}

\author{
Han Si ${ }^{1,2}$, Zhan-Yu Zhang ${ }^{1,2 *}$, Bao-Ping Feng ${ }^{1,2}$, Yang Su ${ }^{1,2}$, \\ Li-Ting Sheng ${ }^{1,2}$, Ahmad Bakour ${ }^{1}$ \\ ${ }^{1}$ College of Water Conservancy and Hydropower Engineering, Hohai University, Nanjing 210098, China \\ ${ }^{2}$ Key Laboratory of Efficient Irrigation-Drainage and Agricultural Soil-Water Environment in Southern China, \\ Ministry of Education, Hohai University, Nanjing 210098, China
}

Received: July 11, 2014

Accepted: August 12, 2015

\begin{abstract}
The grain yields of crops in the Zhuozhang River basin have an important relationship with irrigation due to a mismatch between precipitation and water requirements. In order to obtain optimal irrigation regimes of winter wheat and summer maize in different typical years (wet year, normal year, and dry year), a SWAT model (soil and water assessment tool) was set up in the study area and to simulate different irrigation treatments. According to calibration and validation results of runoff, evapotranspiration and yield simulation, the model showed high applicabilities in the main stream of the Zhuozhang. Different irrigation regimes showed a significant influence on yield, evapotranspiration (ET), water productivity (WP), and even runoff at the outlet. For both winter wheat and summer maize in each typical year, the peak value of crop yield did not meet the maximum value of water productivity. For winter wheat, treatments of W2, W3, and W6 (adopted in wet, normal, and dry years) can guarantee harvest effectively with the average runoff increased by $43.98 \%$, $25.75 \%$, and $6.38 \%$, respectively, compared with actual irrigation. The average runoff increased by $1.58 \%$, $2.89 \%$, and $4.06 \%$, respectively, with treatments of $\mathrm{C} 8, \mathrm{C} 7$, and $\mathrm{C} 3$ adopted in three typical years during summer maize growing periods.
\end{abstract}

Keywords: optimal irrigation regime, SWAT model, water productivity, crop yield, evapotranspiration

\section{Introduction}

Haihe basin is one of the most prominent areas suffering from a water shortage in China [1-3]. The Zhuozhang River basin, as one of the main water resources in Haihe, is particularly facing water environment deterioration and shortfalls between water supply and demand $[4,5]$. In irrigation season, especially, a great challenge is finding a solution to water allocation between upstream and downstream due to rapid expansion of irrigated agriculture [6, 7]. Downstream storage primarily depends on the release from upstream storage [8]. The grain yields of winter wheat and

*e-mail: zhanyuzh@126.com summer maize, widely cultivated crops in the Zhuozhang basin, have a great relation with irrigation due to a mismatch between precipitation and water requirements [9]. Therefore, how to use water scientifically and rationally and how to improve water use efficiency have become urgent problems.

Many studies have been carried out on optimal irrigation regimes of winter wheat and summer maize based on experimental analysis [10-15]. The results showed that with optimized irrigation scheduling, water use for crops could be reduced by $40 \sim 50 \mathrm{~mm}$ without affecting grain production $[16,17]$. Irrigation during the key growing stage is more important than other stages to crops in areas with limited water supply [18-20]. Appropriate irrigation strategies 
would be beneficial to increase crop yield and water productivity (WP) [21-23]. Researching crop sensitivities to water deficiency is advantageous for realizing optimal water allocation during the whole growing period [24-26]. Previous work of making irrigation regimes according to water production functions has proven that it was an effective approach $[27,28]$. However, the experimental data are not easily obtained due to the complexity of experimental design and limited irrigation experiment stations. Moreover, since there is a great difference of crop irrigation scheme in space domain due to the variability in meteorological and hydrological conditions, it is necessary to guide irrigation timing by a crop growth simulation model [29].

The soil and water assessment tool (SWAT) is a river basin scale model developed to predict the impact of land management practices on water, sediment, and agricultural chemical yields in large complex watersheds over long periods of time [30-34]. Cai et al. [35] applied remote sensing-derived ET to validate the monthly evapotranspiration (ET) simulated by using SWAT in the Zhangweinan River basin and calibrated agricultural management practices and parameters for crop growth. Wang et al. [36] using the adapted SWAT model on the Yangshudang watershed to analyze the ET for paddy fields with different irrigation regimes. However, to our knowledge only a few studies have focused on optimal irrigation regimes for semi-arid areas of northern China based on SWAT models.

The objectives of this research were to:

(i) study the applicability of the SWAT model in the main stream of the Zhuozhang basin based on actual river discharge, ET, and crop yield,

(ii) explore the optimal water-saving irrigation regimes of winter wheat and summer maize in different typical years.

\section{Materials and Methods}

\section{Study Area}

The study area is located in southeastern Shanxi Province, China. It is the main stream of the Zhuozhang River (MZR) with a watershed of 265,459 ha. Its latitude and longitude range from $36^{\circ} 16^{\prime}$ to $37^{\circ} 00^{\prime}$, and from $112^{\circ} 47^{\prime}$ to $113^{\circ} 20^{\prime}$, respectively (Fig. 1). This watershed belongs to a semiarid continental monsoon climate area of a temperate zone, and has $9.8^{\circ} \mathrm{C}$ mean annual temperature. The average annual precipitation is $610.6 \mathrm{~mm}$, with more

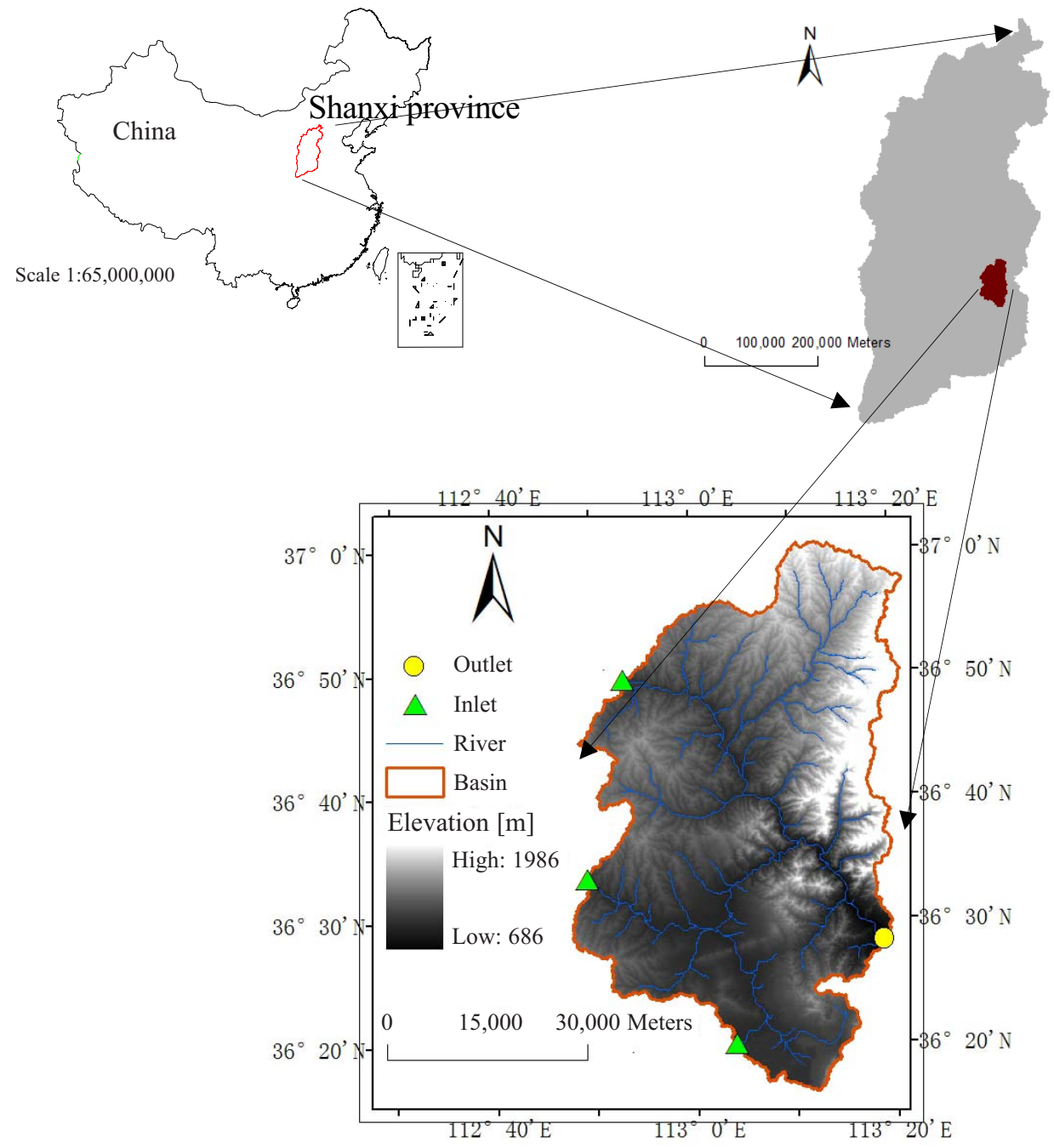

Fig. 1. Location of study area. 
than $70 \%$ falling in the period from June to September. The annual sunshine hours are 2,502, and the annual frostless season is 166 days. Altitude ranges from $686 \mathrm{~m}$ to $1,986 \mathrm{~m}$, mainly mountainous.

Three upstream outlets - the Guanhe, Houwan, and Zhangze reservoirs - are taken as inlets for the main stream of the Zhuozhang. The flow in the river is the highest during flood seasons and very low or zero during dry seasons. The whole basin has just one outlet, Shiliang hydrologic station, which has integrated monitoring data. There is no other large or medium reservoir in the whole watershed.

\section{Model Description}

Based on three digital maps (a digital elevation model (DEM), a land use map, and a soil map), the SWAT model subdivided the watershed into sub-basins and multiple hydrological response units (HRUs) consisting of areas with homogeneous soils, land use, and slope [37-40]. Water balance is the basic driving force of a SWAT model and the basic equation is as follows (all units in $\mathrm{mm}$ ):

$$
s w_{t}=s w_{0}+\sum_{i=1}^{t}\left(R_{d}-Q_{\text {surf }}-E_{a}-W_{s}-Q_{w}\right)(1)
$$

...where $s w_{t}$ is soil water content after t days; $s w_{0}$ is initial soil water content; and $R_{d}, Q_{\text {sur }}, E_{a}, W_{s}$, and $Q_{w}$ are precipitation, surface runoff, evapotranspiration, water entering vadose zone, and return flow, respectively, on day $i$. As precipitation descends, water will be intercepted and held in the vegetation canopy or fall to the soil surface, and then redistributed through water management on the ground. Flow generation from each HRU in a sub-basin is summed and the resulting loads are routed through channels to the watershed outlet.

Evapotranspiration is the main approach for moisture transferring from a watershed. The model offers three options for estimating potential evapotranspiration (PET): Hargreaves [41], Priestley-Taylor [42], and PenmanMonteith [43], of which the third was selected in this research. Actual ET is calculated based on PET and parameters of soil and land uses in the model. Surface runoff occurs whenever the rate of water application to the ground surface exceeds the rate of infiltration. It is estimated with a modification of the SCS curve number method from the United States Department of Agriculture Soil Conservation Service (USDA SCS) $[8,44]$.

SWAT utilizes a plant growth model to simulate all types of land cover. The potential growth in plant biomass on a given day is defined as the increase in biomass under ideal growing conditions. For any plant, a base temperature must be reached before any growth will take place. Above the base temperature, the higher the temperature, the more rapid the growth rate of the plant. As it will be difficult to achieve the best growth situation and yield due to constraints imposed by the environmental, the SWAT model simulates actual crop growth with the consideration of extreme temperatures and water deficiencies.

\section{Data Availability}

In this study, we applied Arc SWAT version 2009 in the ArcGIS (version 9.3) environment. The DEM (Fig. 1) with a resolution of $30 \times 30 \mathrm{~m}$ was obtained from International Scientific \& Technical Data Mirror Site, Computer Network Information Center, Chinese Academy of Sciences (http://datamirror.csdb.cn).

Soil data with key physical and chemical properties such as depth of horizon, percentage of sand, silt, clay, organic carbon, bulk density, saturated hydraulic conductivity, and water content at different tension values for each horizon were obtained from the Harmonized World Soil Database (HWSD) made by the Food and Agriculture Organization of the United Nations (FAO) and International Institute for Applied Systems Analysis (IIASA) at a scale of 1:10,000,000. Soil unit symbols used the FAO-90 classification system [45] and was classified into seven types (Fig. 2). $71.8 \%$ of the soil was classified as calcaric cambisols (Table 1).

The land use map $(1: 250,000)$ was obtained from Data Sharing Infrastructure of Earth System Science (http://www.geodata.cn) (Fig. 3). As two main land-use types, agricultural land-row crops (AGRR) and typicalgrasses (RNG2) accounted for $31.68 \%$ and $37.04 \%$ of the total land area, respectively. Land-use classification circumstance is shown in Table 1.

Meteorological data, daily values of precipitation, maximum and minimum temperatures, solar radiation, relative humidity, and wind speed were obtained from four local hydrological stations and input into the SWAT model. To verify model suitability, simulated flow results should be calibrated by monitoring data. Because of the missing flow data in 2005, the period March-December 1999 served as the warm-up period for the model, and calibration phases were performed for the years 2000 to 2004, while validation phases were 2006 to 2010 .

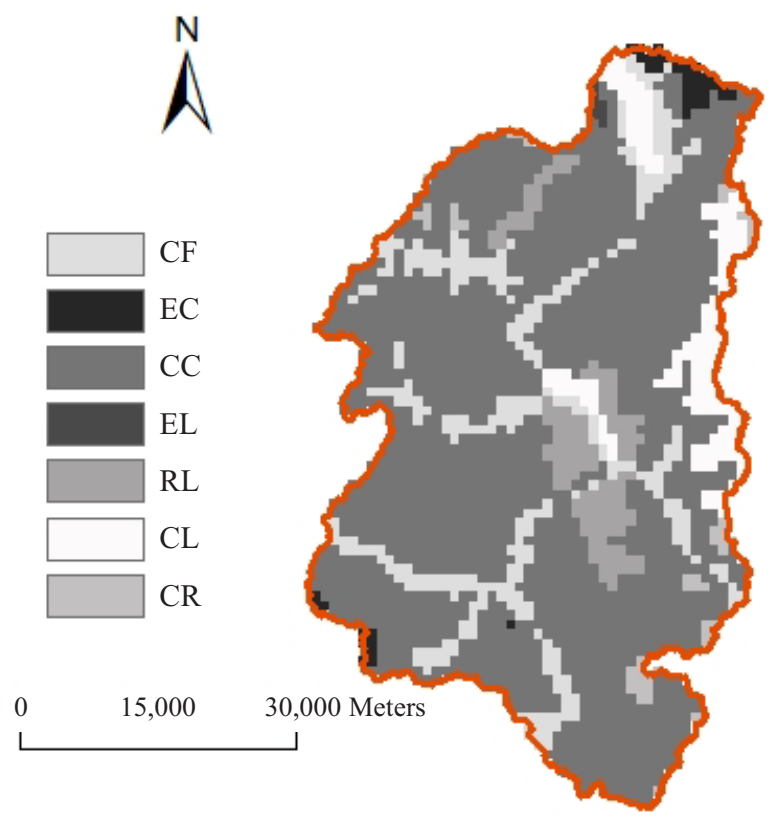

Fig. 2. Major soil types in study area. 
Table 1. Land use classes and soil type classes in study area.

\begin{tabular}{|c|c|c|c|c|c|}
\hline \multicolumn{3}{|c|}{ Land use } & \multicolumn{3}{|c|}{ Soil } \\
\hline Code & Full name & Percentage & Code & Full name & Percentage \\
\hline FRSD & Forest-deciduous & 9.83 & $\mathrm{CF}$ & Calcaric Fluvisols & 12.51 \\
\hline FRS2 & Shrubwood & 12.17 & $\mathrm{EC}$ & Eutric Cambisols & 1.59 \\
\hline RNG1 & Meadow-grasses & 3.35 & $\mathrm{CC}$ & Calcaric Cambisols & 71.8 \\
\hline RNG2 & Typical-grasses & 37.40 & EL & Eutric Leptosols & 0.28 \\
\hline RNGE & Range-grasses & 2.60 & RL & Rendzic Leptosols & 5.47 \\
\hline RICE & Rice & 0.03 & CL & Calcic Luvisols & 6.42 \\
\hline AGRR & Agricultural land-row crops & 31.68 & $\mathrm{CR}$ & Calcari Cregosols & 1.93 \\
\hline URHD & Residential-high density & 1.69 & & & \\
\hline URML & Residential-low density & 0.97 & & & \\
\hline WATR & Water & 0.22 & & & \\
\hline LAN1 & Tidal flat & 0.07 & & & \\
\hline
\end{tabular}

Irrigation Regime Set-Up

AGRR was built as a winter wheat-summer maize rotation for the most widely distributed crops in MZR. Winter wheat was generally sown during early October and harvesting typically occurred during the first 10 days of June. Summer maize was inter-planted into winter wheat 5-7 days prior to harvest to prolong the growth period and ensure that harvesting happens in the last 10 days of September. Irrigation management in this study was mainly based on local practices. Wheat was irrigated four times during growing seasons in most years, which happened in the sowing to over-wintering (SO), turning green to jointing (TJ), jointing to booting (JB), and booting to filling

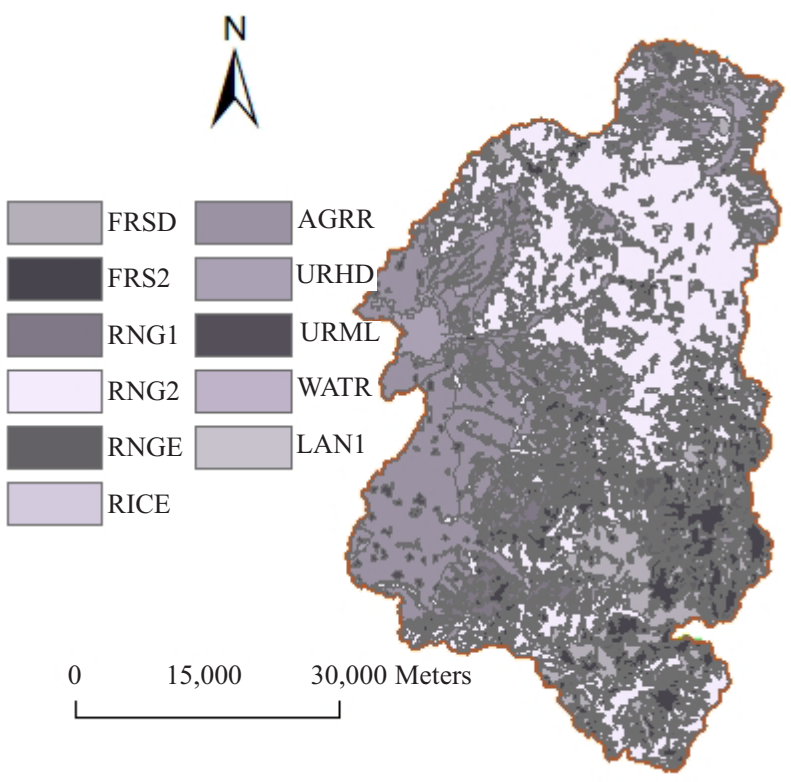

Fig. 3. Major land uses in study area.
(BF) stages. Summer maize was irrigated two to three times during the growing periods, which happened in the sowing to jointing (SJ), jointing to tasseling (JT), and tasseling to filling (TF) stages. The irrigation amount for each event was $30-75 \mathrm{~mm}$. The irrigation date and amount varies every year mainly due to climate conditions and precipitation. Detailed cultivation schedules were based on field investigations considering water-sensitive periods for wheat and maize.

Three typical years (wet year, normal year, and dry year) were selected for researching an optimal irrigation regime. The simulated ET and yield results in these three typical years would be calibrated with measured ET and investigation yield data. Based on precipitation data (from 1952 to 2010) of Shiliang station, 2003, 2001, and 2006 were selected as wet year $\left(\mathrm{T}_{\mathrm{WY}}\right)$, normal year $\left(\mathrm{T}_{\mathrm{NY}}\right)$, and dry year $\left(\mathrm{T}_{\mathrm{DY}}\right)$, respectively. Table 2 presents precipitation distributions in these three typical years, while Table 3 graphically illustrates crop irrigation procedures that have been installed into the model.

\section{Crop Growth Parameters}

It is necessary to set up the main parameters in the model, which has a significant effect on ET and crop yield. SWAT uses potential heat units (PHU)-leaf area index curve to define crop growth processes (Fig. 4). Six parameters are going to quantify leaf area development of various plant species during the growing season, which are maximum potential leaf area index (BLAI), fraction of the plant growing season (FRGRW1), fraction of the maximum leaf area index corresponding to the first point on Fig. 4 (LAIMX1), fraction of the plant growing season (FRGRW2), fraction of the maximum leaf area index corresponding to the second point on Fig. 4 (LAIMX2), and fraction of the growing season when leaf area declines 
Table 2. Precipitation distributions in three typical years.

\begin{tabular}{|c|c|c|c|c|}
\hline & Total precipitation $(\mathrm{mm})$ & Precipitation from June to September $(\mathrm{mm})$ & $\mathrm{W}_{\text {pre }}(\mathrm{mm})$ & $\mathrm{M}_{\text {pre }}(\mathrm{mm})$ \\
\hline $\mathrm{T}_{\mathrm{WY}}$ & 804.6 & 609.8 & 163.0 & 552.0 \\
\hline $\mathrm{T}_{\mathrm{NY}}$ & 528.9 & 431.8 & 134.4 & 426.7 \\
\hline $\mathrm{T}_{\mathrm{DY}}$ & 486.4 & 289.4 & 182.8 & 287.8 \\
\hline
\end{tabular}

$\mathrm{W}_{\text {pre }}$ - precipitation during the whole growing seasons of winter wheat, from crop cultivation day in October of last year to harvest day in the current year.

$\mathrm{M}_{\text {pre }}$ - precipitation during the whole growing seasons of summer maize.

Table 3. Crop irrigation procedures built into the SWAT model.

\begin{tabular}{|c|c|c|c|c|c|c|c|c|c|c|c|c|}
\hline & \multicolumn{7}{|c|}{$\begin{array}{l}\text { Winter wheat irrigation amounts during certain } \\
\text { growing periods }(\mathrm{mm})\end{array}$} & \multicolumn{5}{|c|}{$\begin{array}{l}\text { Summer maize irrigation amounts during certain } \\
\text { growing periods }(\mathrm{mm})\end{array}$} \\
\hline & $\mathrm{SO}$ & OT & $\mathrm{TJ}$ & JB & $\mathrm{BF}$ & $\mathrm{FH}$ & $\begin{array}{c}\text { Total } \\
\text { amount }\end{array}$ & SJ & $\mathrm{JT}$ & $\mathrm{TF}$ & $\mathrm{FH}$ & $\begin{array}{c}\text { Total } \\
\text { amount }\end{array}$ \\
\hline $\mathrm{T}_{\mathrm{WY}}$ & 0 & 0 & 51 & 65 & 60 & 0 & 176 & 50 & 70 & 0 & 0 & 120 \\
\hline $\mathrm{T}_{\mathrm{NY}}$ & 40 & 0 & 60 & 60 & 60 & 0 & 220 & 40 & 60 & 75 & 0 & 175 \\
\hline $\mathrm{T}_{\mathrm{DY}}$ & 45 & 0 & 60 & 70 & 60 & 0 & 235 & 60 & 65 & 70 & 0 & 195 \\
\hline
\end{tabular}

OT - over wintering stage to turning green stage

$\mathrm{FH}$ - filling stage to harvest

Table 4. Crop parameter values built into SWAT model of winter wheat and summer maize.

\begin{tabular}{|l|c|c|c|c|c|c|}
\hline & BLAI & FRGRW1 & LAIMX1 & FRGRW2 & LAIMX2 & DLAI \\
\hline Winter wheat & 4.98 & 0.25 & 0.14 & 0.45 & 0.61 & 0.52 \\
\hline Summer maize & 4.13 & 0.25 & 0.05 & 0.55 & 0.85 & 0.90 \\
\hline
\end{tabular}

(DLAI). The remaining crop parameters adopted default value in the model. Tbase represents base temperature for plant growth $\left({ }^{\circ} \mathrm{C}\right)$. When temperatures drop to minus 0 degrees Celsius in winter, wheat will stop tillering and get into over-wintering stage. Therefore, Tbase of winter wheat was going to take 0 degrees Celsius. For summer maize of northern China, Tbase value could be defined as 10 degrees Celsius [35].

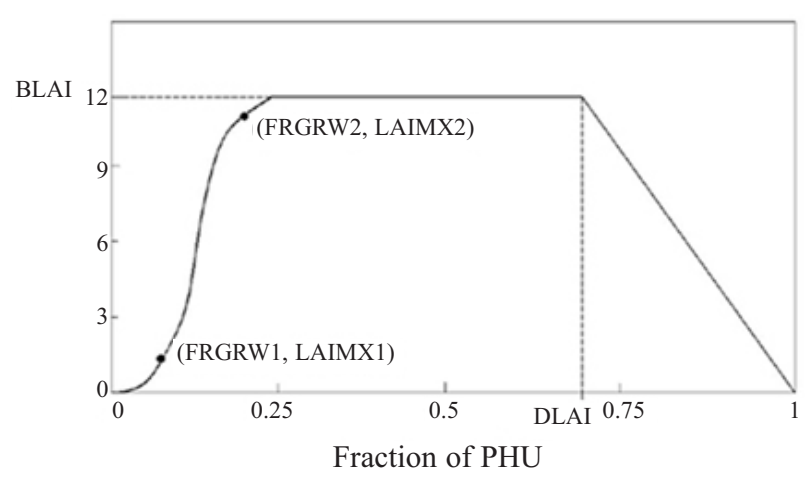

Fig. 4. Leaf area index as a function of fraction of growing season for Alamo switchgrass.
According to Pan et al. [4], experimental data of wheat and maize in Quzhou experimental station from 1999 to 2005 was adopted to define crop parameters. Final values are presented in Table 4.

\section{Model Calibration and Validation}

As it is not feasible to include all parameters being calibrated in SWAT, the most sensitive 11 parameters for runoff and ET values were considered as critical calibration. Final results will be accepted when simulated data act well with actual data. The performance of the model was evaluated by coefficient of determination $\left(\mathrm{R}^{2}\right)$ and NashSutcliffe efficiency (Ens) [32]. In order to make sure of the model accuracy of simulating irrigation management, river discharge, ET, and crop yield participated in the calibration using measured data. Table 5 has a list of the most sensitive parameters and their final values after calibration.

\section{Scenario Analysis}

In order to obtain optimal water-saving irrigation regimes in each typical year of winter wheat and summer maize based on local general irrigation procedures, differ- 
Table 5. Basic parameter settings and variation ranges.

\begin{tabular}{|c|c|c|c|c|c|}
\hline Parameter & Definition & Min. value & Max. value & Calibrated value & File \\
\hline $\mathrm{CN} 2$ & SCS curve number & 35 & 98 & $55 \sim 86$ & .mgt \\
\hline SOL_AWC & Available water capacity of the soil layer & 0 & 1 & $0.147 \sim 0.175$ & .sol \\
\hline SOL_K & Saturated hydraulic conductivity & 0 & 1,000 & $8.89 \sim 19.23$ & sol \\
\hline ESCO & Soil evaporation compensation factor & 0 & 1 & 0.75 & .bsn \\
\hline EPCO & Plant water uptake compensation factor & 0 & 1 & 0.97 & .bsn \\
\hline GW_DELAY & Groundwater delay & 0 & 500 & 50 &.$g w$ \\
\hline GW_REVAP & Groundwater revap coefficient & 0.02 & 0.2 & 0.07 &.$g w$ \\
\hline RCHRG_DP & Deep aquifer percolation factor & 0 & 1 & 0.21 &.$g w$ \\
\hline ALPHA_BF & Baseflow alpha factor & 0 & 1 & 0.5 & gw \\
\hline CH_N2 & Manning's "n" value for main channel & 0.01 & 0.5 & 0.06 & .rte \\
\hline SURLAG & Surface runoff lag time & 0 & 10 & 1.5 & .bsn \\
\hline
\end{tabular}

Table 6. Irrigation treatments of crops in each certain growing period.

\begin{tabular}{|c|c|c|c|c|c|c|c|c|c|c|c|c|c|}
\hline \multicolumn{9}{|c|}{ Winter wheat (mm) } & \multicolumn{5}{c|}{ Summer maize (mm) } \\
\hline Treatment & SO & OT & TJ & JB & BF & FH & $\begin{array}{c}\text { Total } \\
\text { amount }\end{array}$ & Treatment & SJ & JT & TF & FH & $\begin{array}{c}\text { Total } \\
\text { amount }\end{array}$ \\
\hline W1 & 60 & 0 & 0 & 0 & 0 & 0 & 60 & C1 & 0 & 0 & 0 & 0 & 0 \\
\hline W2 & 60 & 0 & 60 & 0 & 0 & 0 & 120 & C2 & 0 & 60 & 0 & 0 & 60 \\
\hline W3 & 60 & 0 & 0 & 60 & 0 & 0 & 120 & C3 & 60 & 60 & 60 & 0 & 180 \\
\hline W4 & 60 & 0 & 0 & 0 & 60 & 0 & 120 & C4 & 60 & 60 & 60 & 60 & 240 \\
\hline W5 & 60 & 0 & 60 & 60 & 0 & 0 & 180 & C5 & 60 & 0 & 0 & 0 & 60 \\
\hline W6 & 60 & 0 & 60 & 0 & 60 & 0 & 180 & C6 & 60 & 0 & 60 & 60 & 180 \\
\hline W7 & 60 & 0 & 0 & 60 & 60 & 0 & 180 & C7 & 60 & 0 & 60 & 0 & 120 \\
\hline W8 & 0 & 0 & 60 & 60 & 60 & 0 & 180 & C8 & 0 & 0 & 60 & 0 & 60 \\
\hline W9 & 60 & 0 & 60 & 60 & 60 & 0 & 240 & & & & \\
\hline
\end{tabular}

ent irrigation treatments were arranged and simulated by calibrated SWAT model. In a few treatments, irrigation time varied with the same total amount. Table 6 graphically illustrates irrigation treatments in each certain growing period.

\section{Results and Discussion}

\section{Model Performance}

Fig. 5 presents a comparison of the simulated and measured monthly flow of Shiliang Station for both calibration (2000-04) and validation (2006-10) phases. The simulated flow followed a similar trend as the observed flow. During the calibration period, $\mathrm{R}^{2}$ and Ens were 0.84 and 0.80 , respectively, at the outlet, which indicated that the model performed very well in the study area. During the validation period, the values of $\mathrm{R}^{2}$ and Ens for the flow reached 0.72 and 0.69 , repectively. During the flood season of validation period in some years (such as 2006), runoff changed greatly so the SWAT model could not simulate well. However, the performance of the simulated flow was overall acceptable.

With remote sensing, monitoring monthly ET values were taken as measured data. Eleven typical sub-basins, the main form of winter wheat-summer maize rotation, were selected for calibration of simulated ET values. Table 7 presents integrated results of coefficient of determination $\left(\mathrm{R}^{2}\right)$ and Nash-Sutcliffe efficiency (Ens). $\mathrm{R}^{2}$ and Ens of subbasins $5,19,45$, and 48 showed lower values, probably due to unavoidable deviation between the actual irrigation schedule and that installed into the model. However, from the whole trend, ET simulation got a comparatively ideal result and was satisfactory for simulation research. 
Table 7. Coefficient of determination and Nash-Sutcliffe efficiency results of ET data for study area.

\begin{tabular}{|l|c|c|c|c|c|c|c|c|c|c|c|}
\hline & sub1 & sub5 & sub9 & sub19 & sub45 & sub48 & sub77 & sub81 & sub106 & sub119 & sub132 \\
\hline $\mathrm{R}^{2}$ & 0.86 & 0.67 & 0.79 & 0.70 & 0.66 & 0.68 & 0.80 & 0.91 & 0.78 & 0.85 & 0.93 \\
\hline Ens & 0.83 & 0.43 & 0.74 & 0.44 & 0.50 & 0.52 & 0.75 & 0.88 & 0.64 & 0.81 & 0.91 \\
\hline
\end{tabular}

Fig. 6 presents average monthly ET of 11 sub-basins and monitored data in three typical years. The statistical analysis showed reasonable agreement between observed and simulated monthly values in these years. ET values showed an "M" curve in each year and had two peaks, in May and August, that corresponded to peak-growth periods of winter wheat and summer maize, respectively.

Production data for wheat and maize were collected by consulting statistical yearbooks in local counties and field investigations. Despite data, we probably have some deviations due to disagreement of statistical references, and they were still essential for model calibration. Though comparing simulated production data of wheat and maize with field data in three typical years, as seen in Table 8, all values of $\mathrm{R}^{2}$ were greater than 0.75 , and Ens values ranged between 0.68 and 0.81 . It is overall reasonable for validation results and could be used to simulated research on crop growth in the study area.

Water productivity $(W P)$ is defined as crop yield divided by water use (evapotranspiration, ET):

\section{$W P=Y / E T\left(\mathrm{~kg} / \mathrm{m}^{3}\right)$}

...where $Y$ is simulated grain yield $(\mathrm{kg} / \mathrm{ha})$.

The total water use of wheat and maize in three typical years was about $400 \mathrm{~mm}$. However, as seen in Table 8, water use in normal years was relatively larger than wet and dry years, which appeared that ET not only had a relationship with precipitation but also was affected by temperature, humidity, and other climate factors. WP varied significantly in each year due to yield variance caused by uneven distribution of precipitation and irrigation amount. The high water use does not meet high production. Therefore, fluctuated yield results and various ET and WP illustrated the existence of an optimal irrigation regime for each crop and difference of sensitivity for water stress between each certain growing period.

\section{Yield, ET, and WP Simulation}

Average yield, ET, and WP of winter wheat and summer maize under different treatments simulated by SWAT

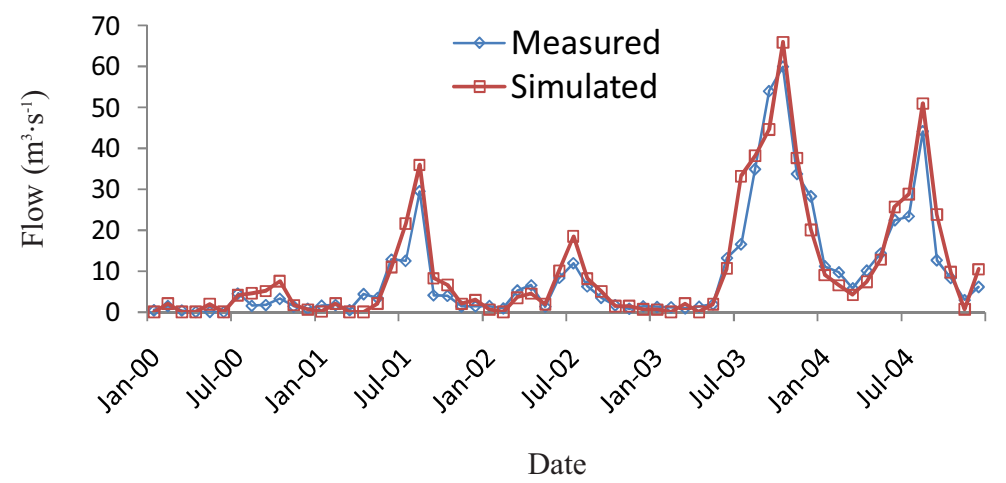

Calibration phase

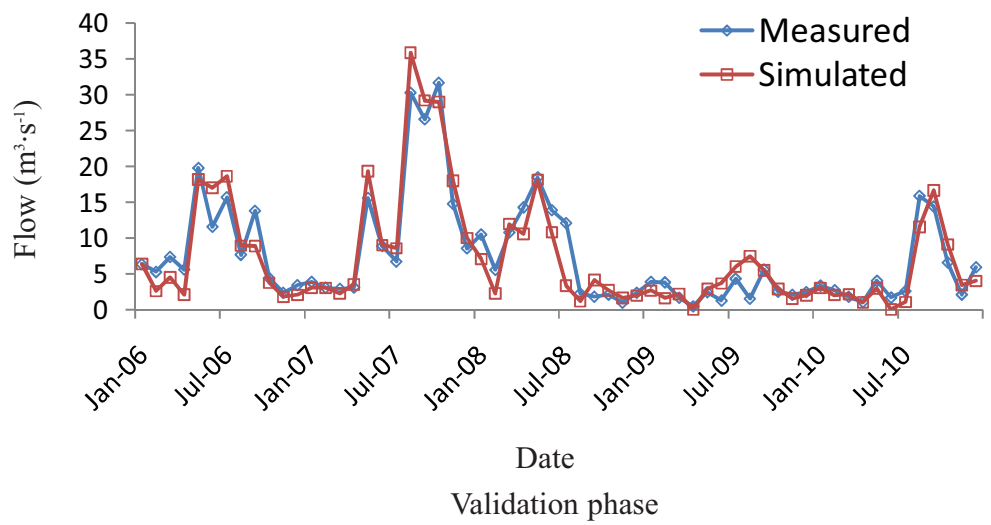

Fig. 5. Comparison of measured and simulated discharge for the study area during calibration phase (2000-04) and validation phase (2006-10) 
Table 8. Actual and simulated yield, water use, and WP of crops in three typical years.

\begin{tabular}{|c|c|c|c|c|c|c|c|c|c|c|c|c|}
\hline & \multicolumn{6}{|c|}{ Winter wheat } & \multicolumn{6}{|c|}{ Summer maize } \\
\hline & $\begin{array}{c}\text { Mean } \\
\text { simulated } \\
\text { yield }(\mathrm{kg} / \mathrm{ha})\end{array}$ & $\begin{array}{c}\text { Mean } \\
\text { actual yield } \\
(\mathrm{kg} / \mathrm{ha})\end{array}$ & $\mathrm{R}^{2}$ & Ens & $\begin{array}{l}\text { Water } \\
\text { use } \\
(\mathrm{mm})\end{array}$ & $\begin{array}{c}\text { WP } \\
\left(\mathrm{kg} / \mathrm{m}^{3}\right)\end{array}$ & $\begin{array}{c}\text { Mean } \\
\text { simulated } \\
\text { yield }(\mathrm{kg} / \mathrm{ha})\end{array}$ & $\begin{array}{c}\text { Mean } \\
\text { actual yield } \\
(\mathrm{kg} / \mathrm{ha})\end{array}$ & $\mathrm{R}^{2}$ & Ens & $\begin{array}{l}\text { Water } \\
\text { use } \\
(\mathrm{mm})\end{array}$ & $\begin{array}{c}\text { WP } \\
\left(\mathrm{kg} / \mathrm{m}^{3}\right)\end{array}$ \\
\hline $\mathrm{T}_{\mathrm{WT}}$ & $5,830.13$ & $5,246.23$ & 0.82 & 0.74 & 363.07 & 1.61 & $6,720.20$ & $6,615.84$ & 0.85 & 0.81 & 382.63 & 1.76 \\
\hline $\mathrm{T}_{\mathrm{NY}}$ & $5,095.85$ & $5,343.32$ & 0.76 & 0.68 & 417.54 & 1.22 & $6,500.14$ & $6,287.13$ & 0.81 & 0.78 & 393.88 & 1.65 \\
\hline $\mathrm{T}_{\mathrm{DY}}$ & $5,495.36$ & $5,751.35$ & 0.75 & 0.69 & 376.07 & 1.46 & $6,263.87$ & $6,483.03$ & 0.79 & 0.70 & 368.90 & 1.70 \\
\hline
\end{tabular}

Table 9. Yield, ET, and WP of winter wheat for various treatments in three typical years.

\begin{tabular}{|l|c|c|c|c|c|c|c|c|c|}
\hline & \multicolumn{3}{|c|}{$\mathrm{T}_{\mathrm{WY}}$} & \multicolumn{3}{c|}{$\mathrm{T}_{\mathrm{NY}}$} & \multicolumn{3}{c|}{$\mathrm{T}_{\mathrm{DY}}$} \\
\cline { 2 - 11 } & $\begin{array}{c}\text { Yield } \\
(\mathrm{kg} / \mathrm{ha})\end{array}$ & $\begin{array}{c}\mathrm{ET} \\
(\mathrm{mm})\end{array}$ & $\begin{array}{c}\mathrm{WP} \\
\left(\mathrm{kg} / \mathrm{m}^{3}\right)\end{array}$ & $\begin{array}{c}\text { Yield } \\
(\mathrm{kg} / \mathrm{ha})\end{array}$ & $\begin{array}{c}\mathrm{ET} \\
(\mathrm{mm})\end{array}$ & $\begin{array}{c}\mathrm{WP} \\
\left(\mathrm{kg} / \mathrm{m}^{3}\right)\end{array}$ & $\begin{array}{c}\text { Yield } \\
(\mathrm{kg} / \mathrm{ha})\end{array}$ & $\begin{array}{c}\text { ET } \\
(\mathrm{mm})\end{array}$ & $\begin{array}{c}\text { WP } \\
\left(\mathrm{kg} / \mathrm{m}^{3}\right)\end{array}$ \\
\hline W1 & $4,134.96^{\mathrm{f}}$ & 295.05 & 1.40 & $3,972.30^{\mathrm{f}}$ & 326.50 & 1.22 & $3,234.29^{\mathrm{e}}$ & 278.04 & 1.16 \\
\hline W2 & $5,785.59^{\mathrm{a}}$ & 335.06 & 1.73 & $4,923.78^{\mathrm{de}}$ & 349.52 & 1.41 & $4,323.39^{\mathrm{d}}$ & 316.11 & 1.37 \\
\hline W3 & $5,525.86^{\mathrm{b}}$ & 342.05 & 1.62 & $5,435.72^{\mathrm{b}}$ & 357.54 & 1.52 & $4,646.83^{\mathrm{c}}$ & 316.04 & 1.47 \\
\hline W4 & $4,980.15^{\mathrm{e}}$ & 347.32 & 1.43 & $5,003.41^{\mathrm{cd}}$ & 363.55 & 1.38 & $4,547.82^{\mathrm{c}}$ & 326.03 & 1.39 \\
\hline W5 & $5,824.67^{\mathrm{a}}$ & 356.05 & 1.64 & $5,520.54^{\mathrm{ab}}$ & 386.52 & 1.43 & $5,098.96^{\mathrm{b}}$ & 356.05 & 1.43 \\
\hline W6 & $5,394.43^{\mathrm{c}}$ & 388.05 & 1.39 & $5,710.17^{\mathrm{a}}$ & 394.53 & 1.45 & $5,482.93^{\mathrm{a}}$ & 359.06 & 1.53 \\
\hline W7 & $5,115.34^{\mathrm{de}}$ & 397.05 & 1.29 & $4,821.91^{\mathrm{e}}$ & 404.54 & 1.19 & $4,527.36^{\mathrm{cd}}$ & 368.03 & 1.23 \\
\hline W9 & $5,652.41^{\mathrm{ab}}$ & 377.07 & 1.50 & $5,170.72^{\mathrm{c}}$ & 421.54 & 1.23 & $5,278.50^{\mathrm{b}}$ & 376.07 & 1.40 \\
\hline
\end{tabular}

The letters represent one-way ANOVA results which are used to evaluate the effects of irrigation methods on crop yield and illustrate if they show significant differences.

Table 10. Yield, ET, and WP of summer maize for various treatments in three typical years.

\begin{tabular}{|c|c|c|c|c|c|c|c|c|c|}
\hline & \multicolumn{3}{|c|}{$\mathrm{T}_{\mathrm{WY}}$} & \multicolumn{3}{c|}{$\mathrm{T}_{\mathrm{NY}}$} & \multicolumn{3}{c|}{$\mathrm{T}_{\mathrm{DY}}$} \\
\cline { 2 - 11 } & $\begin{array}{c}\text { Yield } \\
(\mathrm{kg} / \mathrm{ha})\end{array}$ & $\begin{array}{c}\mathrm{ET} \\
(\mathrm{mm})\end{array}$ & $\begin{array}{c}\text { WP } \\
\left(\mathrm{kg} / \mathrm{m}^{3}\right)\end{array}$ & $\begin{array}{c}\text { Yield } \\
(\mathrm{kg} / \mathrm{ha})\end{array}$ & $\begin{array}{c}\mathrm{ET} \\
(\mathrm{mm})\end{array}$ & $\begin{array}{c}\text { WP } \\
\left(\mathrm{kg} / \mathrm{m}^{3}\right)\end{array}$ & $\begin{array}{c}\text { Yield } \\
(\mathrm{kg} / \mathrm{ha})\end{array}$ & $\begin{array}{c}\mathrm{ET} \\
(\mathrm{mm})\end{array}$ & $\begin{array}{c}\text { WP } \\
\left(\mathrm{kg} / \mathrm{m}^{3}\right)\end{array}$ \\
\hline C1 & $5,534.12^{\mathrm{d}}$ & 307.77 & 1.80 & $4,756.47^{\mathrm{f}}$ & 279.37 & 1.70 & $3,973.29^{\mathrm{f}}$ & 236.97 & 1.68 \\
\hline C2 & $7,080.92^{\mathrm{ab}}$ & 345.60 & 2.05 & $5,618.01^{\mathrm{e}}$ & 318.51 & 1.76 & $5,182.47^{\mathrm{d}}$ & 277.61 & 1.87 \\
\hline C3 & $6,616.88^{\mathrm{bc}}$ & 419.14 & 1.58 & $6,624.27^{\mathrm{b}}$ & 397.29 & 1.67 & $6,405.80^{\mathrm{ab}}$ & 359.16 & 1.78 \\
\hline C4 & $6,101.28^{\mathrm{c}}$ & 449.63 & 1.36 & $6,311.74^{\mathrm{c}}$ & 437.87 & 1.44 & $6,675.93^{\mathrm{a}}$ & 399.82 & 1.67 \\
\hline C5 & $6,565.32^{\mathrm{c}}$ & 344.68 & 1.90 & $6,179.41^{\mathrm{d}}$ & 318.68 & 1.94 & $4,887.35^{\mathrm{e}}$ & 277.91 & 1.76 \\
\hline C6 & $6,898.11^{\mathrm{b}}$ & 417.59 & 1.65 & $6,917.25^{\mathrm{a}}$ & 400.06 & 1.73 & $6,357.01^{\mathrm{b}}$ & 358.21 & 1.77 \\
\hline C7 & $7,201.23^{\mathrm{a}}$ & 381.69 & 1.89 & $6,768.88^{\mathrm{b}}$ & 357.98 & 1.89 & $5,800.09^{\mathrm{c}}$ & 318.72 & 1.82 \\
\hline C8 & $7,166.85^{\mathrm{a}}$ & 341.72 & 2.10 & $6,319.76^{\mathrm{c}}$ & 316.77 & 2.00 & $4,967.08^{\mathrm{de}}$ & 273.52 & 1.82 \\
\hline
\end{tabular}

The letters represent one-way ANOVA results which are used to evaluate the effects of irrigation methods on crop yield and illustrate if they show significant differences.

model are presented in Tables 9 and 10. The one-way ANOVA approach was used to evaluate the effects of irrigation methods on crop yield at $\mathrm{P}<0.05$ using the IBM SPSS Statistics software package. Crop yield showed an increasing trend with the increase of water use, and reached a peak value when water use reached a certain degree. However, the yield decreased instead when water use continued to increase. Crop yield showed significant differences under the same irrigation amount due to various irrigation periods. 


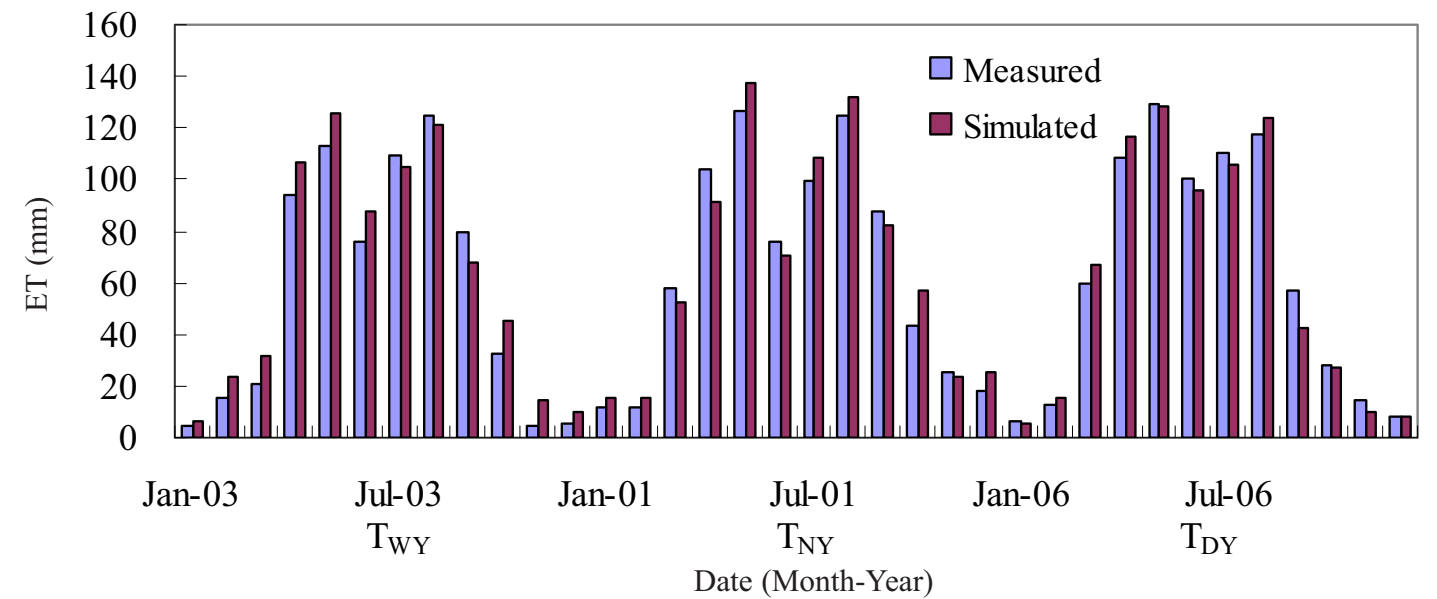

Fig. 6. Comparison of average monthly ET and monitored data in three typical years.

As shown in Table 9, crop yield had the maximum values with the treatments of $\mathrm{W} 5, \mathrm{~W} 6$, and $\mathrm{W} 9$ in $\mathrm{T}_{\mathrm{WY}}, \mathrm{T}_{\mathrm{NY}}$, and $\mathrm{T}_{\mathrm{DY}}$, respectively, while WP reached the peak value under different treatments for each year. In $\mathrm{T}_{\mathrm{WY}}$, treatment of W2, W5, and W8 had no significant influence on wheat yield based on one-way ANOVA $(\mathrm{P}<0.05)$. Treatment W5 recorded the highest yield, when its ET and WP were $356.05 \mathrm{~mm}$ and $1.64 \mathrm{~kg} \cdot \mathrm{m}^{-3}$, respectively. However, treatment W2 showed the minimum ET value and WP was 1.73 $\mathrm{kg} \cdot \mathrm{m}^{-3}$. The data proved that timely irrigation in winter (based on precipitation and supplementary irrigation one time before the jointing stage in $\mathrm{T}_{\mathrm{WY}}$ ) can guarantee harvest effectively and reduce water consumption. Treatment W6 recorded the highest yield in $\mathrm{T}_{\mathrm{NY}}$, while W5 took second place with no significant difference using treatment W6 $(\mathrm{P}<0.05)$. However, ET of treatments W5 and W6 reached $386.52 \mathrm{~mm}$ and $394.53 \mathrm{~mm}$, respectively. WP reached the maximum value under treatment $\mathrm{W} 3$, which had lower yield (decreasing only by $4.81 \%$ compared with W6).
Therefore, in $\mathrm{T}_{\mathrm{NY}}$, treatments of $\mathrm{W} 5$ and $\mathrm{W} 6$ can be selected as optimal irrigation methods in study areas with sufficient water conditions, while W3 should be adopted with limited water. In $\mathrm{T}_{\mathrm{DY}}$, water deficiency in different growth periods led to a reduction in different degrees for wheat yield compared with treatment W9. However, treatment W6 showed no significant influence on crop yield, while water use decreased obviously compared with W9. Therefore, W6 could be selected as optimal irrigation regime, implementing deficit irrigation in JB stage.

As shown in Table 10, treatments of C2, C7, and C8 had no significant influence on maize yields in $\mathrm{T}_{\mathrm{WY}}$. Since precipitation in a wet year can basically meet water requirements during the growing period of summer maize, irrigation would be needed only in the JT or TF stages - the most sensitive stages for water deficiency - to guarantee production. Treatments of $\mathrm{C} 2$ and $\mathrm{C} 8$ were optimal irrigation regimes in $\mathrm{T}_{\mathrm{WY}}$ due to comparatively lower water use, while their WPs were 2.05 and 2.10, respectively. Treatment C6 a)

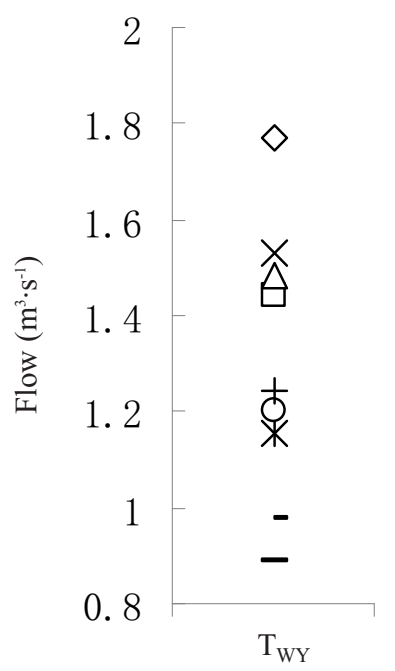

b)

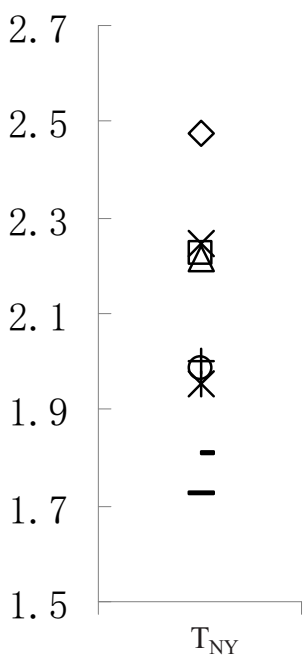

C)

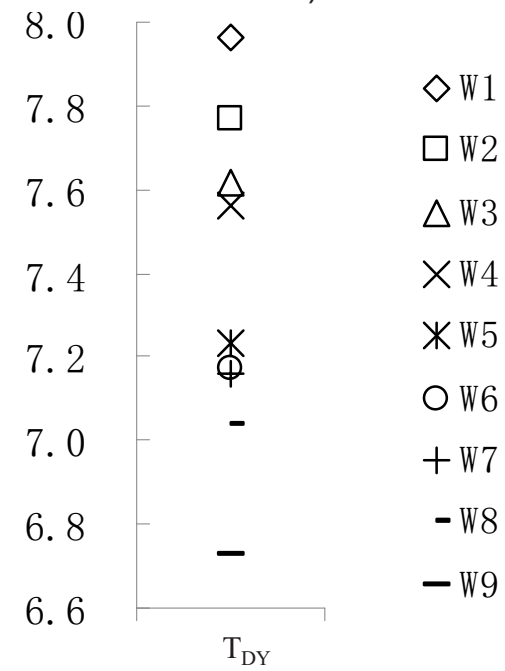

Fig. 7. Average runoff during the whole winter wheat growth periods in $T_{W Y}(a), T_{N Y}(b)$, and $T_{D Y}(c)$ under different irrigation treatments. 

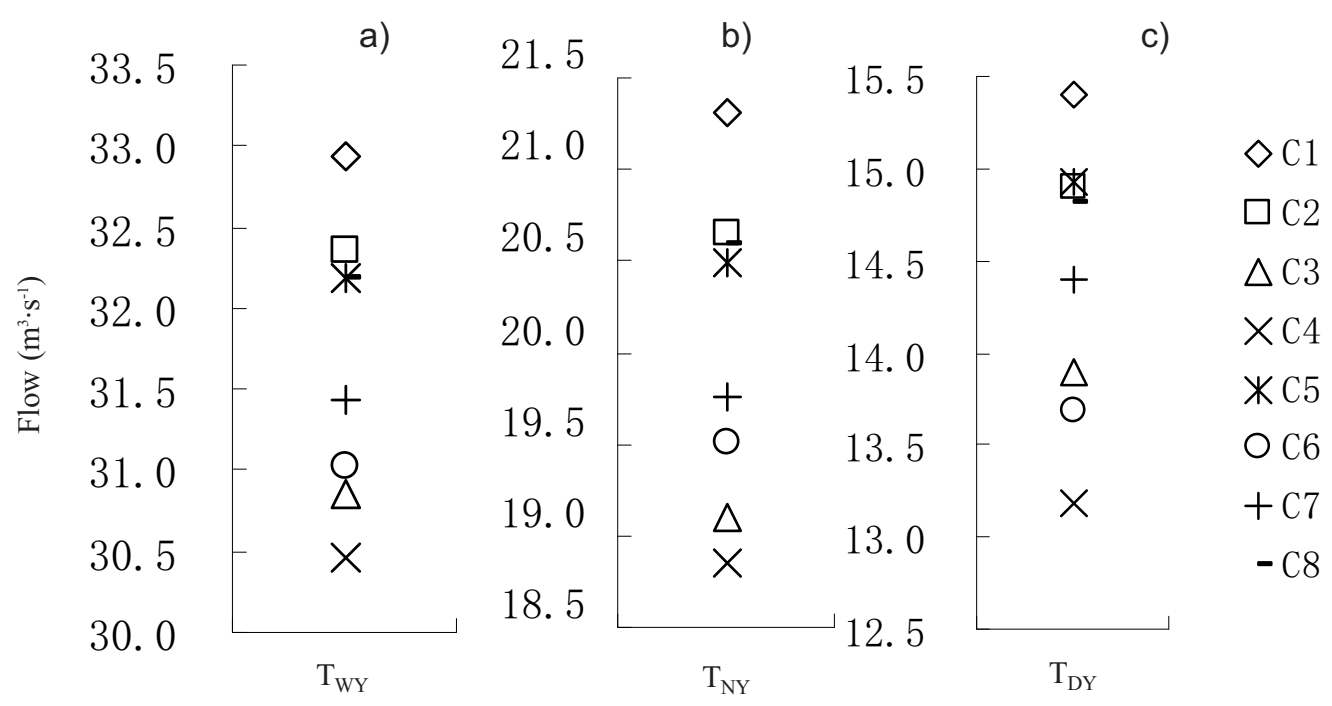

Fig. 8. Average runoff during the whole summer maize growth periods in $\mathrm{T}_{\mathrm{WY}}(\mathrm{a}), \mathrm{T}_{\mathrm{NY}}(\mathrm{b})$, and $\mathrm{T}_{\mathrm{DY}}(\mathrm{c})$ under different irrigation treatments.

recorded the maximum yield in $\mathrm{T}_{\mathrm{NY}}$, but it still had higher ET, which led to comparatively lower WP. Treatment C7 had lower yield, while its ET decreased obviously compare with treatment C6. Therefore, irrigation was necessary at the seedling stage for maximizing yield of summer maize, and it needed two more times after the tasseling stage. Under limited water supply conditions, irrigation for one time after the tasseling stage contributed to increasing water use efficiency clearly with minimum yield loss. In $\mathrm{T}_{\mathrm{DY}}$, treatments of $\mathrm{C} 3$ and $\mathrm{C} 6$ should be selected as optimal irrigation regimes due to minimum yield loss and lower ET compared with treatment $\mathrm{C} 4$, which recorded the highest yield and ET.

\section{Runoff Simulation}

Different irrigation regimes also exerted an influence on the runoff at the outlet. Figs. 7 and 8 illustrated average runoff during the whole growth period of winter wheat and summer maize in three typical years under different irrigation treatments. Runoff decreased with the increase of irrigation frequency. Average runoff showed no significant difference between irrigation treatments with the same irrigation frequency. For winter wheat, the average runoff in three typical years with actual irrigation was $1.00 \mathrm{~m}^{3} \cdot \mathrm{s}^{-1}$, $1.76 \mathrm{~m}^{3} \cdot \mathrm{s}^{-1}$, and $6.74 \mathrm{~m}^{3} \cdot \mathrm{s}^{-1}$. Runoff in $T_{D Y}$ was relatively higher than the other two typical years due to larger precipitation during growing seasons. Since crop yield was the main factor taken into account, based on previous analysis conclusions, treatments of $\mathrm{W} 2, \mathrm{~W} 3$, and $\mathrm{W} 6$, which were adopted by $\mathrm{T}_{\mathrm{WY}}, \mathrm{T}_{\mathrm{NY}}$, and $\mathrm{T}_{\mathrm{DY}}$, can guarantee harvest effectively with the average runoff increased by $43.98 \%$, $25.75 \%$, and $6.38 \%$, respectively. The average runoff increased by $1.58 \%, 2.89 \%$, and $4.06 \%$, respectively, with treatments of $\mathrm{C} 8, \mathrm{C} 7$, and $\mathrm{C} 3$ adopted in three typical years during summer maize growth periods compared with actual irrigation.

\section{Conclusion}

The grain yields of winter wheat and summer maize have a great relationship with irrigation in the main stream of the Zhuozhang River basin. This basin was simulated using SWAT model in order to obtain optimal irrigation regimes in different typical years. According to calibration and validation results of runoff, ET, and yield simulation, the model showed high applicability in MZR.

Base on scenario simulation results, different irrigation regimes exerted a significant influence on yield, ET, WP, and even runoff at the outlet. Crop yield showed an increasing trend with the increase of water use, and reached a peak value with water use at a certain degree. For both winter wheat and summer maize in each typical year, the peak value of crop yield did not meet the maximum value of water productivity. Besides crop yield, ET, and WP, river discharge affected by irrigation management should be taken into account for making optimal irrigation regimes. For winter wheat, treatments of W2, W3, and W6 - which were adopted in $\mathrm{T}_{\mathrm{WY}}, \mathrm{T}_{\mathrm{NY}}$, and $\mathrm{T}_{\mathrm{DY}}-$ can guarantee harvest effectively with the average runoff increased by $43.98 \%$, $25.75 \%$, and $6.38 \%$, respectively, compared with actual irrigation. The average runoff increased by $1.58 \%, 2.89 \%$, and $4.06 \%$, respectively, with treatments of C8, C7, and C3 adopted in three typical years during summer maize growth periods.

\section{Acknowledgements}

This research was supported by the Special Funds for Public welfare scientific research of Ministry of Water Resources in China (No. 201201091-03), Scientific Research Innovation Projects in Jiangsu general Universities (No. CXZZ13_02), and a project funded by the Priority Academic Program Development of Jiangsu 
Higher Education Institutions (No. sys1103). We would like to express our appreciation to the Zhanghe River Upstream Authority, Hebei Province, for providing spot investigations and mass data.

\section{References}

1. QIN C.H., GAN H., WANG L., WANG L. Threshold value for water resources exploitation and utilization in Haihe River basin. Advances in Water Science. 24, (2), 220, 2013 [In Chinese with English Abstract].

2. LI F.P., ZHAN C.S., XU Z.X., JIANG S.S., XIONG J. Remote sensing monitoring on regional crop water productivity in the Haihe River Basin. Journal of Geographical Sciences. 23, (6), 1080, 2013.

3. FANG S., CHEN X.L. Developing drainage as the basis of comprehensive control of drought, waterlogging, salinity and saline groundwater. Irrigation and Drainage. 56, S227, 2007.

4. PAN D., REN L., WANG Y.N. Study on utilization of agricultural water resources with high efficiency in Zhangwei river plain I. Parameter calibration and validation. Journal of China Agricultural University. 16, (5), 13, 2011 [In Chinese with English Abstract].

5. YANG J.Z., JAYAWARDANE N., BLACKWELL J., LU C.Y. Field experimental study of contaminant transport in sewage irrigation and treatment system. J. Hydraul. Eng.ASCE. 4, 72, 2004 [In Chinese with English Abstract].

6. SUN C., REN L. Assessment of surface water resources and evapotranspiration in the Haihe River basin of China using SWAT model. Hydrol. Process. 27, (8), 1200, 2013.

7. DU T.S., KANG S.Z., SUN J.S., ZHANG X.Y., ZHANG J.H. An improved water use efficiency of cereals under temporal and spatial deficit irrigation in north China. Agr. Water Manage. 97, (1), 66, 2010.

8. GARG K.K., BHARATI L., GAUR A., GEORGE B., ACHARYA S., JELLA K., NARASIMHAN B. Spatial mapping of agricultural water productivity using the SWAT model in upper Bhima catchment, India. Irrigation and Drainage. 61, 60, 2012.

9. LIU H.J., KANG Y.H., YAO S.M., SUN Z.Q., LIU S.P., WANG Q.G. Field evaluation on water productivity of Winter wheat under Sprinkler of Surface Irrigation in the North China Plain. Irrigation and Drainage. 62, 37, 2013.

10. JIRIES A., TA'ANY R., ABBASSI B., OROUD I. Agriculture Water Use Efficiency in Wadi Shu'eib Area, Jordan. Pol. J. Environ. Stud. 19, (2), 337, 2010.

11. SAMPATHKUMAR T., PANDIAN B.J., RANGASWAMY M.V., MANICKASUNDARAM P., JEYAKUMAR P. Influence of deficit irrigation on growth, yield and yield parameters of cotton-maize cropping sequence. Agr. Water Manage. 130, 90, 2013

12. ALI H., IQBAL N., AHMAD S., SHAHZAD A.N., SARWAR N. Performance of late sown wheat crop under different planting geometries and irrigation regimes in arid climate. Soil Till. Res. 130, 109, 2013.

13. CELEBI S.Z., DEMIR S., CELEBI R., DURAK E.D., YILMAZ I.H. The effect of Arbuscular Mycorrhizal Fungi (AMF) applications on the silage maize (Zea mays L.) yield in different irrigation regimes. Eur. J. Soil Biol. 46, 302, 2010.

14. OGOLA J.B.O., WHEELER T.R., HARRIS P.M. Effects of nitrogen and irrigation on water use of maize crops. Field Crop. Res. 78, 105, 2002
15. YANG C.H., HUANG G.B., CHAI Q., LUO Z.X. Water use and yield of wheat/maize intercropping under alternate irrigation in the oasis field of northwest China. Field Crop. Res. 124, 426, 2011.

16. ZHANG X.Y., PEI D., CHEN S.Y., SUN H.Y., YANG Y.H. Performance of double-cropped winter wheat - summer maize under minimum irrigation in the north China Plain. Agron. J. 98, (6), 1620, 2006.

17. SUN H.Y., LIU C.M., ZHANG X.Y., SHEN Y.J., ZHANG Y.Q. Effects of irrigation on water balance, yield and WUE of winter wheat in the North China Plain. Agr. Water Manage. 85, 211, 2006.

18. CAI S.H., XU Y., WANG J.S., ZHANG L.H., JING G.F. Relationship between spatio-temporal variability of soil moisture and nutrients and crop yield. Transactions of the Chinese Society of Agricultural Engineering. 25, (12), 26, 2009 [In Chinese with English Abstract].

19. SHAO L.W., ZHANG X.Y., CHEN S.Y., SUN H.Y., WANG Z.H. Effects of irrigation frequency under limited irrigation on root water uptake, yield and water use efficiency of winter wheat. Irrigation and Drainage. 58, 393, 2009.

20. LI Q.Q., DONG B.D., QIAO Y.Z., LIU M.Y., ZHANG J.W. Root growth, available soil water, and water-use efficiency of winter wheat under different irrigation regimes applied at different growth stages in North China. Agr. Water Manage. 97, 1676, 2010.

21. BERGEZ J.E., NOLLEAU S. Maize grain yield variability between irrigation stands: a theoretical study. Agr. Water Manage. 60, 43, 2003

22. LI Q.Q., ZHOU X.B., CHEN Y.H., YU S.L. Water consumption characteristics of winter wheat grown using different planting patterns and deficit irrigation regime. Agr. Water Manage. 105, 8, 2012.

23. QIU G.Y., WANG L.M., HE X.H., ZHANG X.Y., CHEN S.Y., CHEN J., YANG Y.H. Water use efficiency and evapotranspiration of winter wheat and its response to irrigation regime in the north China plain. Agr. Forest Meteorol. 148, 1848, 2008.

24. QURESHI A.S., OWEIS T., KARIMI P., POREHEMMAT J. Water productivity of irrigated wheat and maize in the Karkheh river basin of Iran. Irrigation and Drainage. 59, 264, 2010.

25. PANDEY R.K., MARANVILLE J.W., ADMOU A. Tropical wheat response to irrigation and nitrogen in a Sahelian environment. I. Grain yield, yield components and water use efficiency. Eur. J. Agron. 15, 93, 2001.

26. ZHANG B.C., HUANG G.B., LI F.M. Effect of limited single irrigation on yield of winter wheat and spring maize relay intercropping. Pedosphere. 17, (4), 529, 2007.

27. SALEMI H., SOOM M.A.M., MOUSAVI S.F., GANJI A., LEE T.S., YUSOFF M.K., VERDINEJAD V.R. Irrigation Silage Maize Yield And Water Productivity Response to Deficit Irrigation in an Arid Region. Pol. J. Environ. Stud. 20, (5), 1295, 2011.

28. TONG F.F., GUO P. Simulation and optimization for crop water allocation based on crop water production functions and climate factor under uncertainty. Appl. Math. Model. 37, 7708, 2013.

29. PAN D., REN L., WANG Y.N. Study on utilization of agricultural water resources with high efficiency in Zhangwei river plain II. Crop water production function and optimal irrigation. Journal of China Agricultural University. 16, (5), 20, 2011 [In Chinese with English Abstract]. 
30. ULLRICH A., VOLK M. Application of the Soil and Water Assessment Tool (SWAT) to predict the impact of alternative management practices on water quality and quantity. Agr. Water Manage. 96, 1207, 2009.

31. ROMANOWICZ A.A., VANCLOOSTER M., ROUNSEVELL M., JUNESSE I.L. Sensitivity of the SWAT model to the soil and land use data parametrisation: a case study in the Thyle catchment, Belgium. Ecol. Model. 187, 27, 2005.

32. ZHANG Z.Y., SI H., KONG L.L. Migration of non-point source nitrogen and phosphorus in small watershed based on SWAT model. Transactions of the Chinese Society of Agricultural Engineering. 29, (2), 93, 2013 [In Chinese with English Abstract].

33. HE H.M., ZHOU J., ZHANG W.C. Modelling the impacts of environmental changes on hydrological regimes in the Hei River Watershed, China. Global and Planetary Change. 61, 175, 2008.

34. OEURNG C., SAUVAGE S., SÁNCHEZ-PÉREZ J.M. Assessment of hydrology, sediment and particulate organic carbon yield in a large agricultural catchment using the SWAT model. J. Hydrol. 401, 145, 2011.

35. CAI X.T., XU Z.X., SU B.L., YU W.D. Distributed simulation for regional evapotranspiration and verification by using remote sensing. Transactions of the Chinese Society of Agricultural Engineering. 25, (10), 154, 2009 [In Chinese with English Abstract].

36. WANG J.P., CUI Y.L. Simulation of regional evapotranspiration in different irrigation methods based on adapted SWAT distributed hydrological model. Engineering Journal of Wuhan University. 42, (5), 605, 2009.

37. SRIDHAR V., NAYAK A. Implications of climate-driven variability and trends for the hydrologic assessment of the
Reynolds Creek Experimental Watershed, Idaho. J. Hydrol. 385, 183, 2010.

38. WU Y.P., LIU S.G., GALLANT A.L. Predicting impacts of increased $\mathrm{CO}_{2}$ and climate change on the water cycle and water quality in the semiarid James River Basin of the Midwestern USA. Sci. Total Environ. 430, 150, 2012.

39. JONES C., SULTAN M., YAN E., MILEWSKI A., HUSSEIN M., AL-DOUSARI A., AL-KAISY S., BECKER R. Hydrologic impacts of engineering projects on the Tigris Euphrates system and its marshlands. J. Hydrol. 353, 59, 2008.

40. BÄRLUND I., KIRKKALA T., MALVE O., KÄMÄRI J. Assessing SWAT model performance in the evaluation of management actions for the implementation of the Water Framework Directive in a Finnish catchment. Environ. Modell. Softw. 22, 719, 2007.

41. HARGREAVES G.H., SAMANI Z.A. Reference crop evapotranspiration from ambient air temperature. App. Eng. Agric. 1, 96, 1985.

42. PRIESTLEY C.H.B., TAYLOR R.J. On the assessment of surface heat flux and evaporation using large-scale parameters. Mon. Weather Rev. 100, 81, 1972.

43. MONTEITH J.L., MOSS C.J. Climate and the efficiency of crop production in Britain. Philos. T. Rot. Soc. B. 281, 277, 1965.

44. USDA SOIL CONSERVATION SERVICE. National Engineering Handbook. Hydrology Section 4, (Chapters 410), 1972.

45. FAO. Guidelines for Soil Profile Description, third edition. Soil Resources, Management and Conservation Service, Land and Water Development Division, FAO, Rome. 1990. 